\title{
PRODUCTION OF CAMPTOTHECIN FROM ENDOPHYTIC FUNGI AND CHARACTERIZATION BY HIGH-PERFORMANCE LIQUID CHROMATOGRAPHY AND ANTICANCER ACTIVITY AGAINST COLON CANCER CELL LINE
}

\author{
ASWINI A, SOUNDHARI C* \\ Department of Microbiology, Valliammal College for Women, Chennai, Tamil Nadu, India. Email: drcsoundhari@gmail.com \\ Received: 04 April 2017, Revised and Accepted: 29 November 2017
}

\section{ABSTRACT}

Objective: Scientists are showing increasing interest in studying fungal endophytes as sources of novel and biologically active compounds. The present study was attempted to isolate and characterize camptothecin (СРT) from endophytic fungus Aspergillus niger isolated from Indian Piper betel plant and detection of its anticancer potential on colon cancer cell line.

Methods: The production of CPT was confirmed by high-performance liquid chromatography techniques. The effect of CPT on hematopoietic cell transplantation (HCT) colon cancer cell line was studied by MTT assay.

Results: The amount of CPT which is isolated from A. niger was found to be around $0.175 \mathrm{mg} / \mathrm{L}$. Significant death of HCT cells was observed and was non-toxic to normal vero cell line.

Conclusion: Hence, CPT can be used as a potential lead compound in cancer research.

Keywords: Camptothecin, Endophytic fungi, Anticancer effect, Colon carcinoma cell line HCT 15.

(C) 2018 The Authors. Published by Innovare Academic Sciences Pvt Ltd. This is an open access article under the CC BY license (http://creativecommons. org/licenses/by/4. 0/) DOI: http://dx.doi.org/10.22159/ajpcr.2018.v11i3.18921

\section{INTRODUCTION}

Microorganisms are potential sources of bioactive compounds with extensive capacity for the discovery of novel molecules for drug discovery [1-3].

Biological products are reliable source of lead drugs with more than $40 \%$ of new chemical entities reported until 2005 having been derived from microbes. Endophytes are microorganisms that live intracellularly and/or intercellularly inside the tissues of higher plants and do not cause any symptoms on the plants in which they live. Endophytes have proven to be good sources of bioactive natural products $[4,5]$. Endophytic fungi are symbiotically associated with plants. They develop special mechanism to penetrate into the host tissue. They adapt themselves to the environment by genetic variation, including uptake of some host DNA into their own genomes [6]. This gene transfer might have led to the ability of certain endophytes to biosynthesize some phytochemicals originally produced by the host plant [7]. Combination of inducing factors from both plants and endophytic fungi increases the accumulation of secondary metabolites in plants and fungi, respectively [4]. Research studies reveal that plants and endophytic fungi have similar but distinct metabolic pathways for production of secondary metabolites.

Since the discovery of the compound paclitaxel (Taxol) from the endophytic fungus Taxomyces andreanae in 1993, scientists are shown increasing interests in studying various fungal endophytes as sources of novel and biologically active compounds.

Cancer is a major killer disease and a global problem with more than 6 million new cases is reported every year. Cancer is characterized by unregulated growth and spread of abnormal cells, which can result in death if not controlled. It accounts for 7.4 million, about $13 \%$ of all deaths in 2014 [8]. The anticancer drugs show non-specific toxicity to proliferating normal cells, possess enormous side effects, and are not effective against many forms of cancer [9].
Camptothecin (CPT), a pentacyclic quinoline alkaloid, a potent antineoplastic agent was first isolated from the wood of C. acuminata decaisne (Nyssaceae) a plant native to mainland China [10]. The primary action mechanism of CPT is inhibiting the intranuclear enzyme topoisomerase 1 which is required in DNA replication. Puri et al., 2005, first reported an endophytic fungus Entrophospora infrequens obtained from Nothapodytes foetida that had the ability to produce CPT [11]. Later, CPT was successfully isolated from two endophytic Fusarium solani strains MTCC 9667 and MTCC 9668 [12]. These findings showed that the fungi could be an alternative resource to produce CPT and its analogs.

Betel vine (Piper betel L.) belongs to genus Piper of the family Piperaceae. Leaves of $P$. betel posses several bioactivities and are used in traditional medicinal systems. Many research studies on $P$. betel have reported that it contains a number of important phytoconstituents which exhibit anticancer, anti-allergic, antibacterial, antifungal, antioxidant, antidiabetic, gastroprotective, cytotoxic, antiplatelet, and wound healing activity [13].

With this background about the role of endophytes in the production of bioactive compounds, the present study was attempted to isolate and characterize CPT from endophytic fungus Aspergillus niger isolated from Indian beetle nut plant and detection of its anticancer potential on colon cancer cell line.

\section{METHODS}

Collection of sample

The betel leaves were collected in sterile polythene bags from the market (Fig. 1). Taxonomic identification was made by Plant Anatomy Research Centre, Tambaram, Tamil Nadu.

\section{Processing of samples}

The collected samples were first washed thoroughly in running tap water. Nearly ten segments from a leaf were screened for the presence 


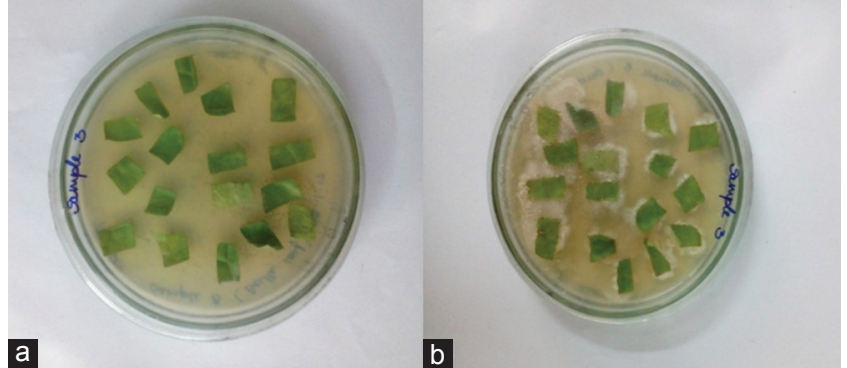

Fig. 1: (a) Sabouraud dextrose agar (SDA) plate with beetle leaves, (b) SDA plate showing endophytic fungi

of fungal endophytes. The leaves were surface sterilized by submerging them in $70 \%$ ethanol for $5 \mathrm{~s}$, immersed in $4 \%$ sodium hypochlorite for $90 \mathrm{~s}$, and rinsed in sterile distilled water. The surface sterilized segments were placed on Sabouraud dextrose agar (SDA) plates supplemented with $10 \mu \mathrm{g} / \mathrm{ml}$ streptomycin as an antibiotic to suppress bacterial growth. The inoculated plates were incubated at $28 \pm 2^{\circ} \mathrm{C}$ for 7-10 days. Emerging hypae were transferred to fresh SDA containing peptones and dextrose and further incubated at $28 \pm 2^{\circ} \mathrm{C}$.

\section{Isolation of fungal endophytes}

The Petri plates were incubated in room temperature. The hyphae, which grew out from the tissues, were transferred to fresh SDA slants and were maintained by subculturing. To prevent the rapidly growing fungi from inhibiting the slow-growing species, the former was removed as soon as they appeared on the plates [14].

\section{Identification of the fungi}

The isolated endophytic fungi from betel nut were identified down to species level with the help by LPCB. The non-sporulating sterile forms were separated into culture groups based on their colony morphology, hyphal characteristics, presence of sclerotia (masses of short-celled, lobed, and closely packed hyphae), and pigmentation as described earlier [15].

\section{Enrichment of fungal endophyte}

The endophytic fungi isolated in the present study were inoculated into a liquid SDA broth for enrichment. The enriched fungal organism was used for the CPT production.

\section{Production and extraction of CPT}

Endophytic fungal isolates obtained were screened for the detection of CPT. Fungal organism isolated in this study was grown in fungal growth enrichment liquid media containing peptone 1.0 and dextrose 4.0. Enrichment broth containing mycelium was used as inoculum. The production media were kept for 10 days on a shaker with $150 \mathrm{rpm}$ at $28^{\circ} \mathrm{C}$. After incubation, the fungal isolates were filtered through cheesecloth. The harvested mycelia were dried and macerated. The homogenate and cell-free broth were extracted 3 times with an equal volume of chloroform and methanol in a 4:1 ratio. This organic solvent was removed by rotatry evaporation at $30^{\circ} \mathrm{C}$. The prepared extracts were subjected to high-performance liquid chromatography (HPLC) with standard CPT for the detection of CPT.

\section{HPLC conditions}

CPT extraction was characterized using HPLC. Solutions were directly analyzed by HPLC (liquid sorb RP- 18, $25 \mathrm{~cm} \times 10 \mu \mathrm{m}$; gradient elusion 0.04, chloroform: Ether 4:1 upto 1:1, $10 \mathrm{~min}$, fluorate $3.5 \mathrm{ml} / \mathrm{min}$ ). Ultraviolet (UV) detection $254 \mathrm{~nm}$.

\section{Cytotoxicity activity}

\section{Cell line and culture}

Vero cell lines were obtained from NCCS, Pune. The cells were maintained in DMEM with $10 \% \mathrm{FBS}$, penicillin $(100 \mathrm{U} / \mathrm{ml})$, and streptomycin $(100$ $\mu \mathrm{g} / \mathrm{ml}$ ) in a humidified atmosphere of $50 \mu \mathrm{g} / \mathrm{ml} \mathrm{CO}_{2}$ at $37^{\circ} \mathrm{C}$.
In vitro assay for cytotoxicity activity (MTT assay) [16]

Cells $\left(1 \times 10^{5} /\right.$ well $)$ were plated in 24 -well plates and incubated in $37^{\circ} \mathrm{C}$ with $5 \% \mathrm{CO}_{2}$ condition. After the cell reaches the confluence, the sample was added and incubated for $24 \mathrm{~h}$. After incubation, the sample was removed from the well and washed with phosphate-buffered saline (pH 7.4) or MEM without serum. $100 \mu \mathrm{L} /$ well $(5 \mathrm{mg} / \mathrm{ml})$ of $0.5 \%$ 3-(4,5-dimethyl-2-thiazolyl)-2,5-diphenyl--tetrazolium bromide (MTT) was added and incubated for $4 \mathrm{~h}$. After incubation, $1 \mathrm{ml}$ of dimethyl sulfoxide (DMSO) was added in all the wells. The absorbance at $570 \mathrm{~nm}$ was measured with UV spectrophotometer using DMSO as the blank. Measurements were performed and the concentration required for a $50 \%$ inhibition $\left(\mathrm{CC}_{50}\right)$ was determined graphically. The \% cell viability was calculated using the following formula:

$\%$ cell viability $=$ A570 of treated cells $/$ A570 of control cells $\times 100$

Graphs are plotted using the \% of cell viability at Y-axis and concentration of the sample in X-axis. Cell control and sample control are included in each assay to compare the full cell viability assessments.

\section{Anticancer activity}

Cell line and culture

Colon carcinoma cell line HCT 15 cell line (human colorectal carcinoma) was obtained from NCCS, Pune. The cells were maintained in DMEM with $10 \% \mathrm{FBS}$, penicillin $(100 \mathrm{U} / \mathrm{ml})$, and streptomycin $(100 \mu \mathrm{g} / \mathrm{ml})$ in a humidified atmosphere of $50 \mu \mathrm{g} / \mathrm{ml} \mathrm{CO}_{2}$ at $37^{\circ} \mathrm{C}$.

In vitro assay for anticancer activity (MTT assay) (Mosmann, 1983) Cells $\left(1 \times 10^{5} /\right.$ well) were plated in 24-well plates and incubated [16] in $37^{\circ} \mathrm{C}$ with $5 \% \mathrm{CO}_{2}$ condition. After the cell reaches the confluence, the sample was added and incubated for $24 \mathrm{~h}$. After incubation, the sample was removed from the well and washed with phosphate-buffered saline ( $\mathrm{pH}$ 7.4) or DMEM without serum. $100 \mu \mathrm{l} /$ well $(5 \mathrm{mg} / \mathrm{ml})$ of $0.5 \%$ MTT was added and incubated for $4 \mathrm{~h}$. After incubation, $1 \mathrm{ml}$ of DMSO was added in all the wells. The absorbance at $570 \mathrm{~nm}$ was measured with UV-spectrophotometer using DMSO as the blank. Measurements were performed and the concentration required for a IC50 was determined graphically. The $\%$ cell viability was calculated using the following formula:

$\%$ cell viability $=\mathrm{A} 570$ of treated cells $/ \mathrm{A} 570$ of control cells $\times 100$

Graphs are plotted using the \% of cell viability at Y-axis and concentration of the sample in X-axis. Cell control and sample control are included in each assay to compare the full cell viability assessments.

\section{RESULTS}

Isolation and identification of endophytes

The endophytic fungi $A$. niger in the present study were isolated from medicinally important plant $P$. betel. Leaves were cut with the help of sterile scalpel and placed on the surface of SDA plate supplemented with $10 \mu \mathrm{g} / \mathrm{ml}$ streptomycin (Fig 1a and b).

The endophytic fungi were grown on SDA medium to study cultural characters such as color and nature of the growth of the colony and maintained by subculturing.

\section{Production and extraction of CPT}

Endophytic fungal isolates obtained were growth liquid media containing peptone 1.0 and dextrose 4.0 for production of CPT.

\section{Chromatographic analysis}

The isolated sample and standard CPT were subjected to HPLC. The retention time (RT) of the sample was found to be 10.84 min when compared to that of the authentic CPT $10.32 \mathrm{~min}$. This confirmed the presence of CPT (Fig. 2a and b). CPT content of the sample was detected by comparing the RT with that of the sample. The area of the standard was compared with the area of sample, and the amount of CPT was calculated by the following equation: 
$\mathrm{CPT}=\frac{\text { Standard concentration } \times \text { total area of the sample }}{\text { Total area of the standard }}$

\section{Cytotoxic effect of isolated CPT}

Viability test by MTT assay

The effect of CPT on colon cancer cell line was studied in comparison to standard camptothecin. The isolated CPT showed a potent anticancer activity against HCT cells. Significant death of HCT cells was observed in dose-dependent manner from $1000 \mu \mathrm{g} / \mathrm{ml}, 500 \mu \mathrm{g} / \mathrm{ml} 250 \mu \mathrm{g} / \mathrm{ml}$, and $125 \mu \mathrm{g} / \mathrm{ml}$ showed anticancer activity to HCT cell line.

IC50 value of standard camptothecin after $24 \mathrm{~h}$ was found to be $31.25 \mu \mathrm{g} / \mathrm{ml}$. (Figs. 3 and 5 and Table 1) and IC50 value of isolated camptothecin after $24 \mathrm{~h}$ was found to be $29.88 \%$. The $\mathrm{IC}_{50}$ value after $24 \mathrm{~h}$ was found to be $29.88 \%$ at $1000 \mu \mathrm{g} / \mathrm{ml}$ and $52.56 \%$ at $62.5 \mu \mathrm{g} / \mathrm{ml}$ (Figs. 4-6 and Table 2). However, the isolated CPT was nontoxic to vero cell line from $500 \mu \mathrm{g} / \mathrm{ml}$ with $\mathrm{IC}_{50}$ of $52.13 \%$ (Figs. 7 and 8 and Table 3).

\section{DISCUSSION}

The widespread misuse of antibiotics for the treatment of microbial infections has led to the emergence and spread of drug-resistant strains. The rise in the rate of infections from multidrug-resistant microbes is recognized globally as a major health crisis. CPT are known to possess potent anticancer [17].

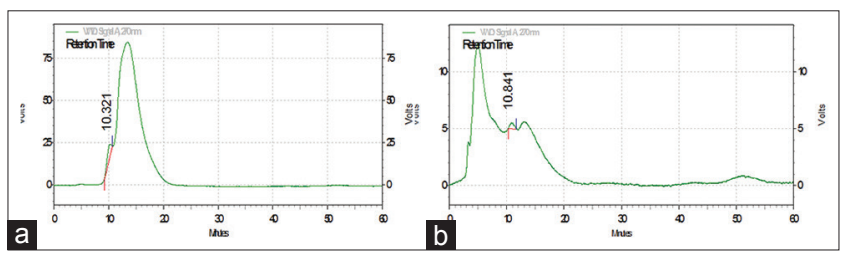

Fig. 2: (a) Standard camptothecin, (b) sample

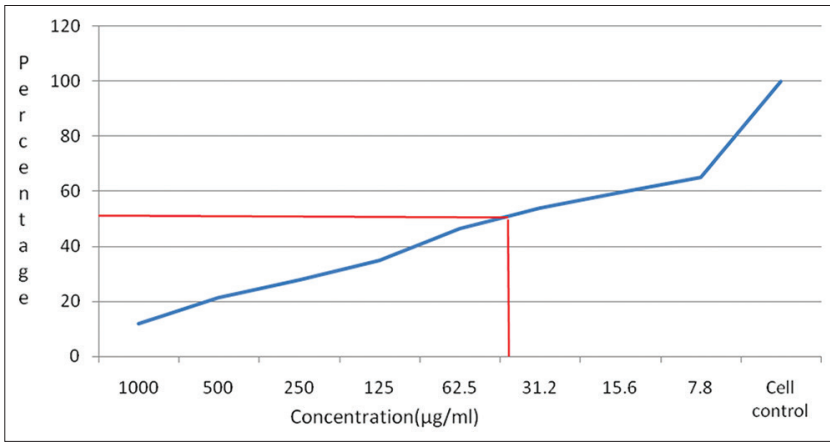

Fig. 3: Graphical representation of anticancer effect of Standard Colon carcinoma cell line HCT 15 transplantation cell line

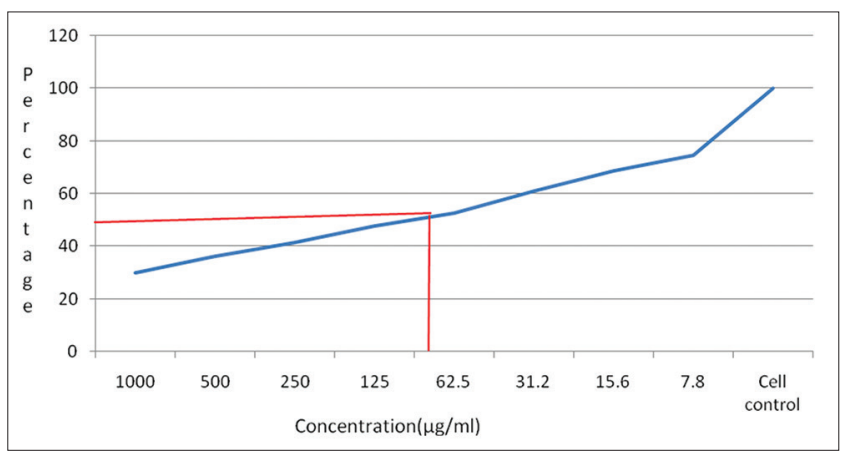

Fig. 4: Graphical representation of anticancer effect of sample Colon carcinoma cell line HCT 15 transplantation cell line
Analysis of the fungal endophytes from various research study shows that many potential pathogenic species or genera have also been identified as endophytes. Genera that are found to be in common include Alternaria, Cladosporium, Colletotrichum, Fusarium, Nigrospora, and Phoma. Saprotrophic taxa that were isolated as endophytes in the present study were A. niger and were screened for the production of CPT.

Leaves were inoculated into SDA, and the hyphae were transferred to fresh medium as mentioned earlier. We did not observe other microbes such as bacteria and actinomycetes during isolation. The endophytic fungi isolated were brought to pure culture form. Stock cultures were maintained by subculturing at regular intervals. After growth at temperature $28^{\circ} \mathrm{C}$ for 7 days, the slants were maintained at $15^{\circ} \mathrm{C}$. From actively growing stock cultures, subcultures were made on fresh slants, and after 7 days, incubation was used as the starting material for fermentation experiments for isolation of CPT.

For studying the cultural and morphological characters, the endophytic fungi were grown on SDA medium. Cultural characters such as color and nature of the growth of the colony were determined by visual observation. Morphological characters of the fungus such as mycelia, conidiophores, and conidia in culture were microscopically studied.

Table 1: Anticancer effect of standard CPT on HCT cell line

\begin{tabular}{llll}
\hline $\begin{array}{l}\text { Concentration } \\
(\boldsymbol{\mu g} / \mathbf{m l})\end{array}$ & Dilutions & Absorbance (O.D) & $\begin{array}{l}\text { Cell } \\
\text { viability }(\%)\end{array}$ \\
\hline 1000 & Neat & 0.150 & 11.85 \\
500 & $1: 1$ & 0.270 & 21.34 \\
250 & $1: 2$ & 0.352 & 27.82 \\
125 & $1: 4$ & 0.442 & 34.94 \\
62.5 & $1: 8$ & 0.587 & 46.40 \\
31.2 & $1: 16$ & 0.680 & 53.75 \\
15.6 & $1: 32$ & 0.755 & 59.76 \\
7.8 & $1: 64$ & 0.824 & 65.13 \\
Cell control & - & 1.265 & 100 \\
\hline
\end{tabular}

Colon carcinoma cell line HCT 15, CPT: Camptothecin

Table 2 Anticancer effect of sample CPT on HCT cell line

\begin{tabular}{llll}
\hline $\begin{array}{l}\text { Concentration } \\
(\boldsymbol{\mu g} / \mathbf{m l})\end{array}$ & Dilutions & Absorbance (O.D) & $\begin{array}{l}\text { Cell } \\
\text { viability (\%) }\end{array}$ \\
\hline 1000 & Neat & 0.378 & 29.88 \\
500 & $1: 1$ & 0.459 & 36.28 \\
250 & $1: 2$ & 0.524 & 41.42 \\
125 & $1: 4$ & 0.603 & 47.66 \\
62.5 & $1: 8$ & 0.665 & 52.56 \\
31.2 & $1: 16$ & 0.771 & 60.94 \\
15.6 & $1: 32$ & 0.868 & 68.61 \\
7.8 & $1: 64$ & 0.945 & 74.70 \\
Cell control & - & 1.265 & 100 \\
\hline
\end{tabular}

CPT: Camptothecin, Colon carcinoma cell line HCT 15

Table 3: Cytotoxicity effect of sample camptothecin extract on vero cell line

\begin{tabular}{llll}
\hline $\begin{array}{l}\text { Concentration } \\
(\boldsymbol{\mu g} / \mathbf{m l})\end{array}$ & Dilutions & Absorbance (O.D) & $\begin{array}{l}\text { Cell } \\
\text { viability (\%) }\end{array}$ \\
\hline 1000 & Neat & 0.810 & 44.87 \\
500 & $1: 1$ & 0.941 & 52.13 \\
250 & $1: 2$ & 1.043 & 57.78 \\
125 & $1: 4$ & 1.161 & 64.32 \\
62.5 & $1: 8$ & 1.342 & 74.34 \\
31.2 & $1: 16$ & 1.453 & 80.49 \\
15.6 & $1: 32$ & 1.614 & 89.41 \\
7.8 & $1: 64$ & 1.756 & 97.28 \\
Cell control & - & 1.805 & 100 \\
\hline
\end{tabular}


Endophytic fungi isolated from the leaves of $P$. betle and screened for CPT production. The CPT was characterized in comparison to the standard purchased from Sigma Aldrich by HPLC. The presence of CPT in the samples was detected by comparing with the RT of the standard sample The plant extract analyzed by HPLC showed chromatographically (Fig. 2a) homogenous peak with baseline separation and closely the same RT (RT = 10 rnin) (Fig. 2b). The quantity of CPT in the sample was found to be $0.175 \mathrm{mg}$. In the previous study, CPT was isolated from bark extracts of Nothapodytes nimmoniana and analyzed by HPLC and reported chromatographically homogenous peaks with baseline separation and same RT at 7.05 min parallel to standard CPT [18]. In vitro cytotoxicity of the CPT was screened against vero cells at different concentrations, and the viability of cells was confirmed using MTT assay and was found to be non-toxic- $\mathrm{CC}_{50}$ from the concentration of $500 \mu \mathrm{g} / \mathrm{ml}$.

Many studies showed that the anticancer potential of CPT may end up in apoptosis $[19,20]$. The anticancer activity against colon cancerous cell lines was determined by MTT assay. Anticancer activity of CPT
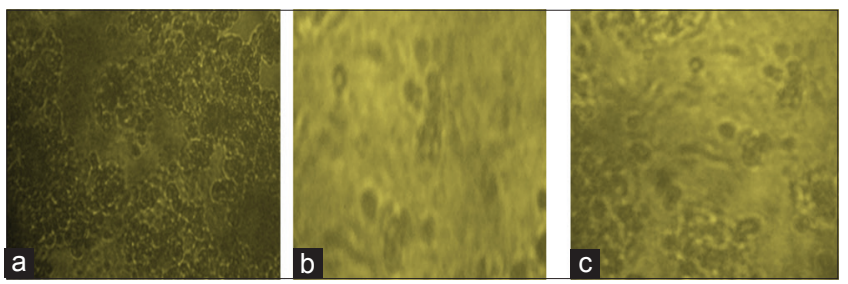

Fig. 5: Anticancer effect of standard camptothecin on Colon carcinoma cell line HCT 15, (a) normal HCT cell line, (b) toxicity $1000 \mu \mathrm{g} / \mathrm{ml}$, (c) non-toxic $-31.2 \mu \mathrm{g} / \mathrm{ml}$

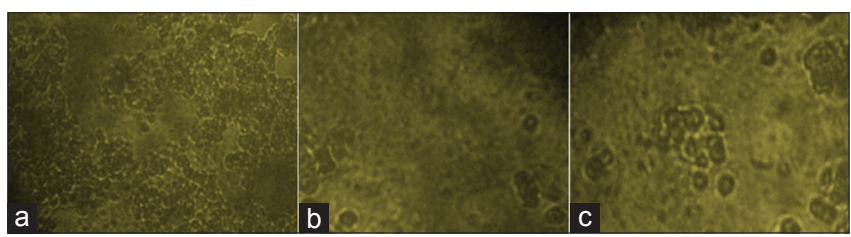

Fig. 6: Anticancer effect of sample camptothecin on Colon carcinoma cell line HCT 15, (a) normal HCT cell line, (b) toxicity $1000 \mu \mathrm{g} / \mathrm{ml}$, (c) non-toxic - $62.5 \mu \mathrm{g} / \mathrm{ml}$

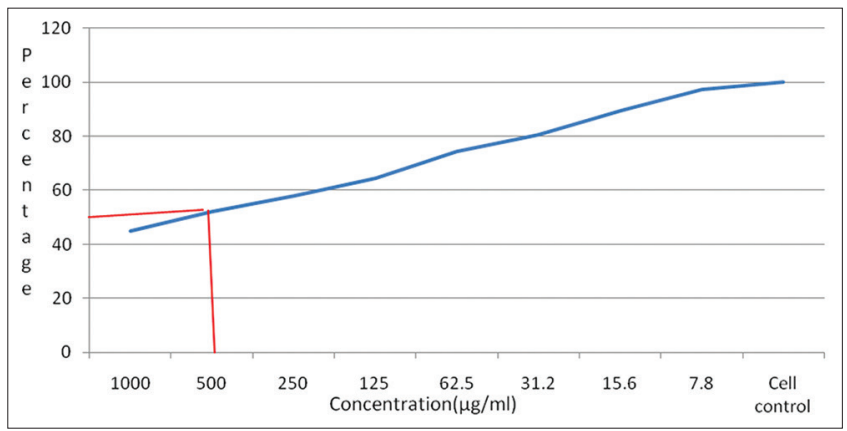

Fig. 7: Graphical representation of cytotoxicity effect of sample camptothecin extract on vero cell line
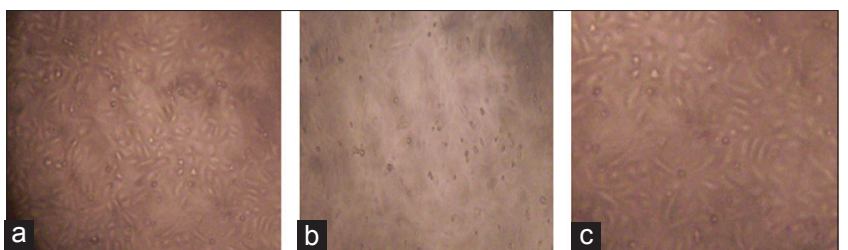

Fig. 8: Cytotoxicity effect of sample camptothecin on vero cell line, (a) normal vero cell line, (b) toxicity - $1000 \mu \mathrm{g} / \mathrm{mL}$, (c) non-toxic $500 \mu \mathrm{g} / \mathrm{mL}$ was done against HCT cells showed significant death of HCT cells till $62.5 \mu \mathrm{g} / \mathrm{ml}$. CPT-treated cells clearly showed alteration in cell morphologies and shrinkage and the alteration rate of the treated cells increased in a dose-dependent manner. It was interesting to note that higher concentrations of CPT were not toxic to Vero cells.

Similar antitumor activity of CPT with apoptotic changes was reported by on MCF-7 cell lines [21]. Ganesan et al., 2015 [22], isolated CPT and in vitro cytotoxicity of CPT was screened against human cervical cancer HeLa cells. A significant death in the HeLa cells was observed in $100 \mu \mathrm{g} /$ $\mathrm{ml}$ of CPT in a dose-dependent manner.

The investigation revealed the endophytic A. niger isolated from P. beetle produced secondary metabolite CPT, by producing such biologically active compounds, the endophytic fungal population may be assisting the host to successfully withstand environment. The isolated CPT exhibited significant anticancer activity to colon cancer cell line HCT. The findings of this study also suggest that CPT is a useful anticancer drug lead for innovative and improved pharmaceuticals.

This present study revealed the endophytic existence of $A$. niger in beetle leaves. The endophytic fungi $A$. niger proved to be an efficient source for the isolation of secondary metabolite CPT. The isolated CPT can be demonstrated a significant anticancer activity against colon cancer cell line. Hence, CPT can be used as a potential lead compound in cancer research.

\section{AUTHORS CONTRIBUTION}

Soundhari C, (corresponding author) designed the work; the actual laboratory work was carried by Aswini A (first author) under the supervision of corresponding author. The manuscript was designed and carefully reviewed by corresponding author.

\section{CONFLICT OF INTEREST}

None declared.

\section{REFERENCES}

1. Porras-Alfaro A, Bayman P. Hidden fungi, emergent properties: Endophytes and microbiomes. Annu Rev Phytopathol 2011;49:291-315.

2. Keller NP, Turner G, Bennett JW. Fungal secondary metabolism-from biochemistry to genomics. Nat Rev Microbiol 2005;3:937-47.

3. Demain AL. Pharmaceutically active secondary metabolites of microorganism. Appl Microbiol Biotechnol 1993;52:455-63.

4. Li J, Zhao GZ, Chen HH, Wang HB, Qin S, Zhu WY, et al. Antitumour and antimicrobial activities of endophytic streptomycetes from pharmaceutical plants in rainforest. Lett Appl Microbiol 2008:47:574-80.

5. Tan RX, Zou WX. Endophytes: A rich source of functional metabolites. Nat Prod Rep 2001;18:448-59.

6. Germaine K, Keogh E, Garcia-Cabellos G, Borremans B, Lelie D, Barac $\mathrm{T}$, et al. Colonisation of poplar trees by gfp expressing bacterial endophytes. FEMS Microbiol Ecol 2004;48:109-18.

7. Stierle A, Strobel G, Stierle D. Taxol and taxane production by Taxomyces andreanae, an endophytic fungus of pacific yew. Science 1993;260:214-6.

8. WHO. WHO Mortality Database. Fact sheet No. 297. Geneva: WHO; 2009.

9. Gangadevi, Muthumary. Taxol, an anticancer drug produced by an endophytic fungus -Bartalinia robillardoides Tassi, isolated from medicinal plant, Agele marmelos Correa ex Roxb agents: An overview. Adv Drug Deliv 2009;61:1177-88.

10. Wall ME, Wani MC, Cook CE, Palmer KH, McPhail GA. The isolation and structure of camptothecin, a novel alkaloid leukemia and tumor inihibitor from Camptotheca accuminata A. J Am Chem Soc 1996;88:3888-90.

11. Puri SC, Verma V, Amna T, Qazi GN, Spiteller M. An endophytic fungus from Nothapodytes foetida that produces camptothecin. J Nat Prod 2005;68:1717-9.

12. Amna T, Puri SC, Verma V, Sharma JP, Khajuria RK, Musarrat J, et al. Bioreactor studies on the endophytic fungus Entrophospora infrequens for the production of an anti-cancer alkaloid camptothecin. Can J 
Microbial 2006;52:189-96

13. Kangralkar VA, Kulkarni AR. In vitro antitumor activity of alcoholic extract of Piper betel leaf. Res J Pharm Biol Chem Sci 2013;4:1558-61.

14. Bills GF. Isolation and analysis of endophytic fungal communities from woody plants. Endophytic Fungi in Grass and Woody Plants Systematic, Ecology, and Evolution. USA: American Phytopathological Society Press; 1996. p. 31-65.

15. Forhlich J, Hyde KD, Petrini O. Endophytic fungi associated with palms. Mycol Res 2012;104:1202-12.

16. Mosmann T. Rapid colorimetric assay for cellular growth and survival: Application to proliferation and cytotoxicity assays. J Immunol Methods 1983;65:55-63.

17. Maliepaard M, Scheffer GL, Faneyte IF, van Gastelen MA, Pijnenborg AC, Schinkel AH, et al. Subcellular localization and distribution of the breast cancer resistance protein transporter in normal human tissues. Cancer Res 2001;61:3458-64.
18. Hertzberg RP, Caranfa MJ, Hecht SM. On the mechanism of topoisomerase I inhibition by camptothecin: Evidence for binding to an enzyme-DNA complex. Biochemistry 1989;28:4629-38.

19. Makin G, Dive C. Apoptosis and cancer chemotherapy. Trends Cell Biol 2001;11:22-6.

20. Chu C, Xu J, Cheng D, Li X, Tong S, Yan J, et al. Anti-proliferative and apoptosis-inducing effects of camptothecin-20(s)-O-(2pyrazolyl-1)acetic ester in human breast tumor MCF-7 cells. Molecules 2014;19:4941-55.

21. Patil A, Patil S, Mahure S, Kale A. UV, FTIR, HPLC confirmation of camptothecin an anticancer metabolite from bark extract of Nothapodytes nimmoniana. Am J Ethnomed 2014;1:174-85.

22. Ganesan N, Rajendran R, Ilanchezhiyan S. Nyctanthes arbor-tristis Linn. Associated fungal endophyte Aspergillus niger derived isolation of Camptothecin for its antimicrobial and cytotoxic activity. Scigen J Sci Technol 2015;1:6-13. 